Proc. Estonian Acad. Sci. Geol., 1998, 47, 3, 195-216

\title{
THE ORDOVICIAN CLITAMBONITIDINE BRACHIOPOD GENUS VELLAMO IN ESTONIA
}

\author{
Oive TINN
}

Institute of Geology, University of Tartu, Vanemuise 46, EE-2400 Tartu, Estonia; e-mail: otinn@math.ut.ee

Received 2 March 1998, in revised form 27 March 1998

\begin{abstract}
Vellamo Öpik, 1930 is a cosmopolitan Ordovician brachiopod genus originating from the epicontinental seas of the Baltoscandian Palaeobasin. As a result of the systematic revision of the Estonian material, 16 Vellamo species are described or discussed. The morphological characters of taxa are presented. Special attention is paid to the ontogenetical changes in the shell morphology, as the earliest growth stages are closely similar in all species of the genus. On the basis of the stratigraphical distribution three successive stages in the development of the Estonian species are distinguished.
\end{abstract}

Key words: Ordovician, clitambonitidine brachiopods, morphology, stratigraphy.

\section{INTRODUCTION}

The genus Vellamo Öpik, 1930 with more than 30 species, has a wide geographical distribution. It has been recorded from the East European Platform, the British Isles, North America, western slope of the Ural Mountains and possibly from Algeria, Belgium, and Tasmania. Sixteen species have been reported from Estonia, Ingria (St Petersburg region of Russia), and Podolia. The northwestern part of the East European Platform is very likely the origination area of the genus ranging here from the Llanvirn up to the end of the Ordovician.

The studied Estonian collections include nearly 800 well-preserved specimens from 65 outcrops and 6 drillcores (Figure). The character list of 16 Vellamo species (Table 1) has been compiled for the present study, based on the emended diagnoses (given in this paper) or original diagnoses. Data matrix shows high variability of certain species, which can be explained with the different growth stages and natural intraspecific variability.

The described specimens are housed in the Museum of the Institute of Geology, University of Tartu (TUG), Institute of Geology at Tallinn Technical 
University (IGT), and Estonian Museum of Natural History (MNH). The studied material comprises all holotypes of the Vellamo species of Öpik (1930a), except for Vellamo viruana Öpik, 1930, whose holotype is presumably lost.

\section{HISTORY OF STUDY}

The first species of Vellamo was described by Eichwald as Orthis verneuilii in 1841. Pahlen (1877) described Orthisina pyramidalis and a subspecies Orthisina verneuilii wesenbergiensis.

Öpik erected Vellamo as a new subgenus of the genus Clitambonites Pander, 1830 (Öpik, 1930a), noting a high interarea, fine costellation, and strong chilidium. He assigned six East Baltic species to the genus: Orthisina trigonula Eichwald, $O$. pyramidalis Pahlen, $O$. complectens Wiman, $O$. emarginata Pahlen, Orthis verneuilii Eichwald, and $O$. sinuata Pahlen. Also three British species Skenidium? Shallockiense Davidson (considered by him as a synonym of Clitambonites (Vellamo) pyramidalis (Pahlen)), C. complectens (Wiman) var. albida Reed, and $O$. adscendens Davidson, non Pander; and two American species C. diversus (Shaler) and C. rogerensis Foerste were regarded as belonging to the genus in the same work.

Öpik (1930a) described also two new Vellamo species: Clitambonites (Vellamo) parvus and $C$. (V.) ultimus. In a different paper (Öpik, 1930b) another new species, $C$. (V.) viruanus, was erected, based on a single ventral valve.

Schuchert and Cooper (1932) who regarded Vellamo in the rank of a genus mentioned that it differs from Clitambonites in important details (position of the interarea, sculpture of the surface, shape of the spondylium). As to phylogeny of the clitambonitidine taxa, the authors regarded Apomatella, Pahlenella, and Vellamo as sister groups, and the genus Clinambon as having its roots in Vellamo. They noted the European origin of the superfamily Clitambonitacea and its later expansion to North America. Seven American species, 11 European species, and 5 subspecies were listed in the genus.

Öpik (1934) gave a 10-point collation of the genera Clitambonites Pander and Vellamo Öpik. The absence of imbrication, flat or slightly convex dorsal valve, large foramen, high ventral interarea, spondylium simplex, and the asymmetry of the ventral valve were pointed out for Vellamo. That work comprised a thorough review of morphology and the description of 19 species and subspecies; 12 of them were new. Three species, assigned in his previous paper (Öpik, 1930a) to Vellamo, were transferred to other genera: Pahlenella trigonula (Eichwald), Kullervo complectens (Wiman), and Ilmarinia sinuata (Pahlen). The phylogenetic scheme was given, showing a common ancestor with Apomatella, Ilmarinia, and Clinambon.

In the early 1950 s D. Kaljo summarized his research on Vellamo. The manuscript is deposited at the Institute of Geology, University of Tartu (Kaljo, 1951). 


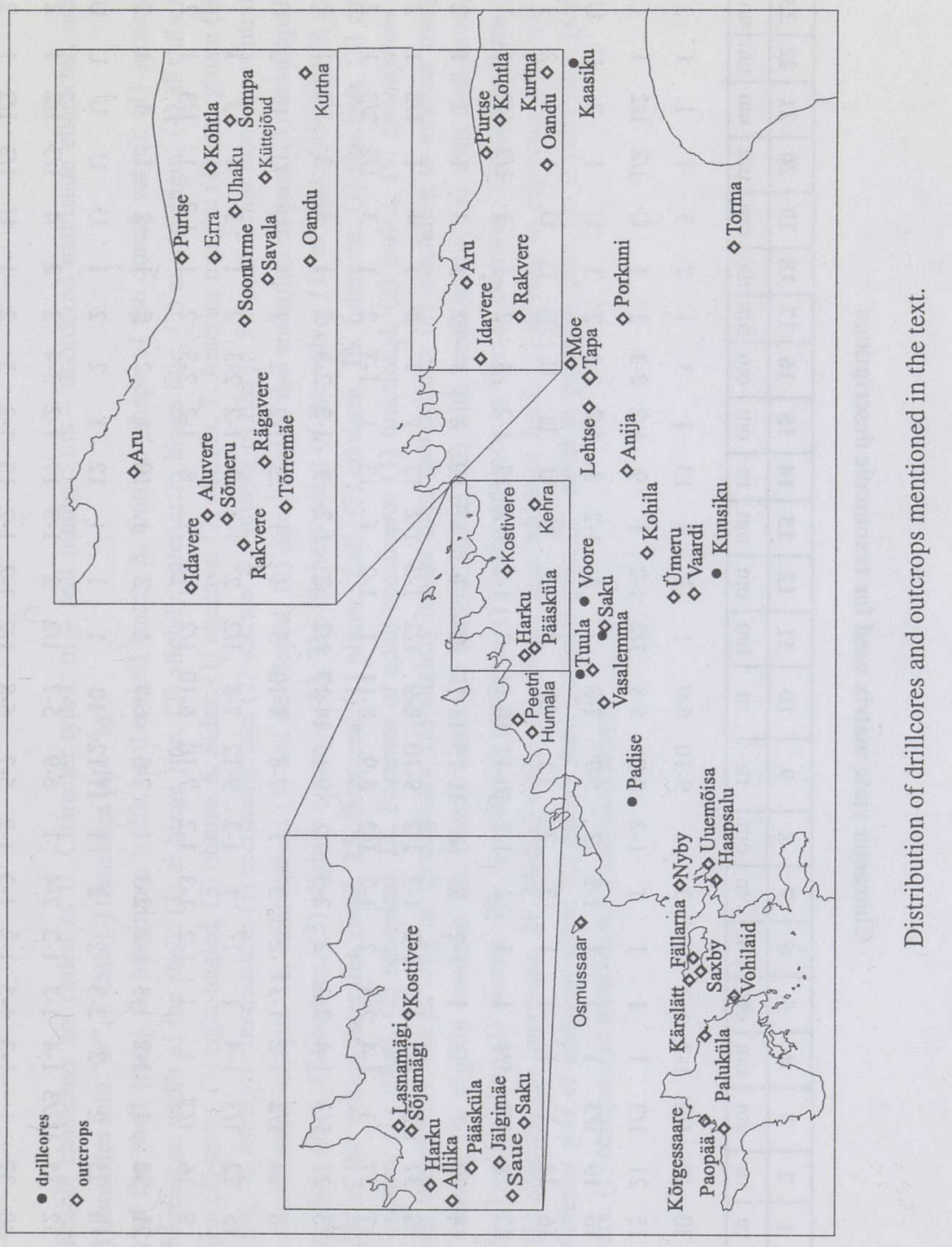


$\frac{\sqrt{0}}{\frac{1}{0}}$

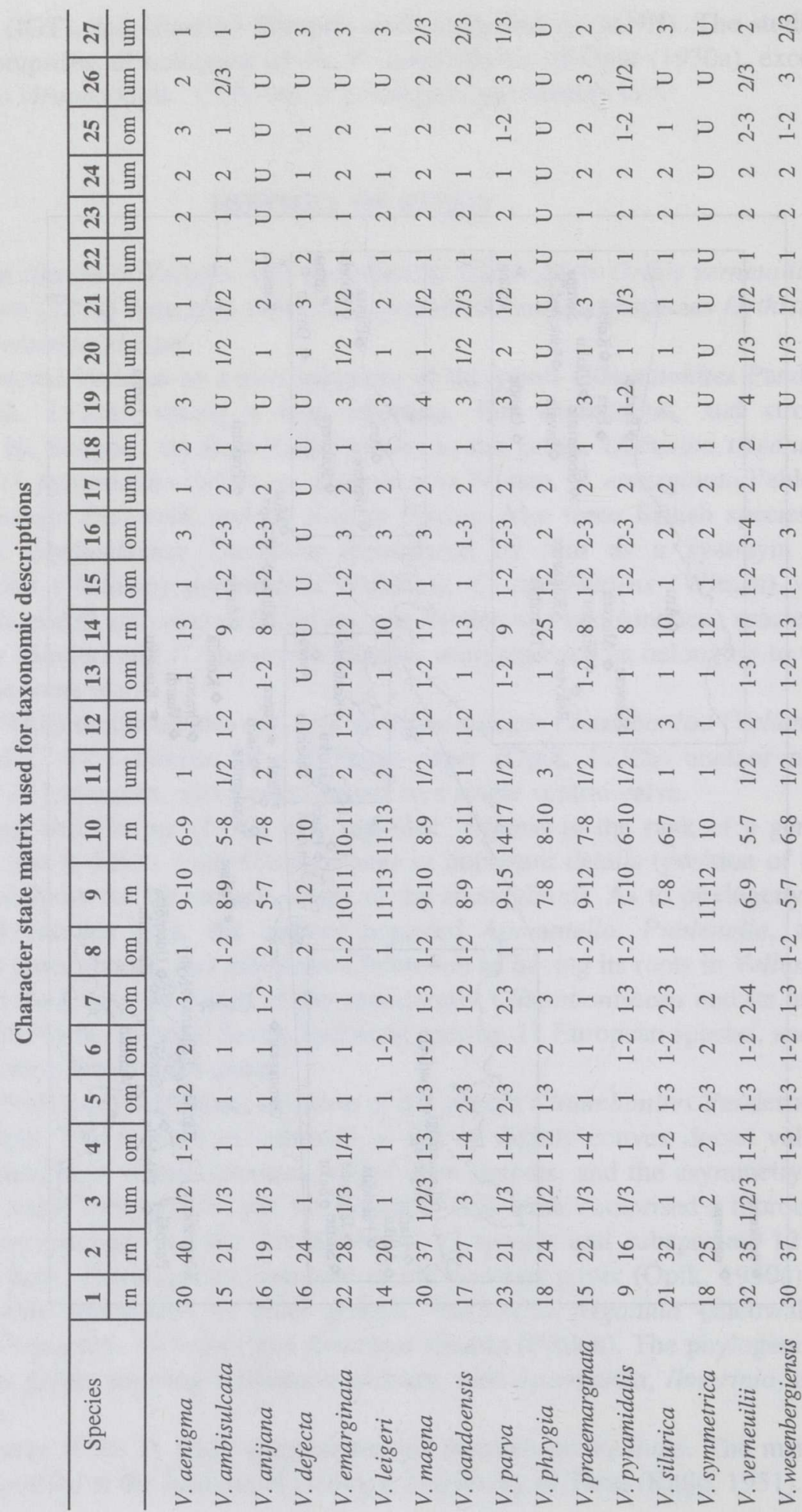




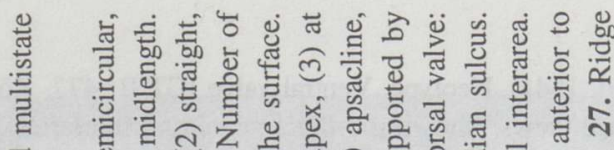

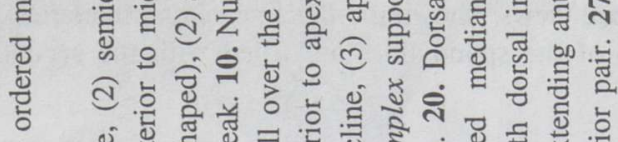

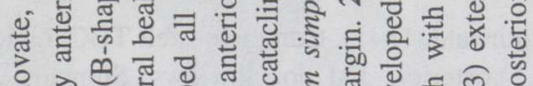

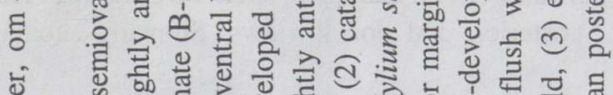

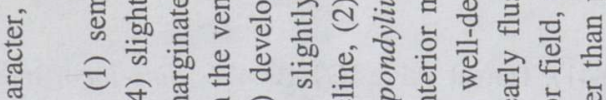

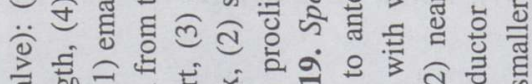

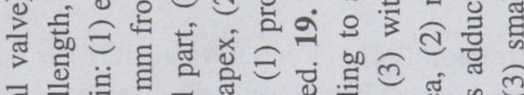

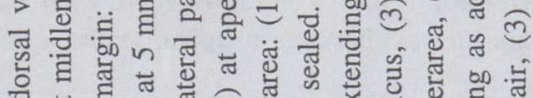

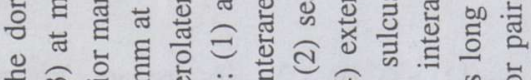

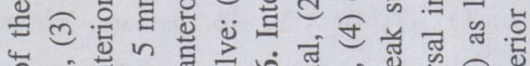

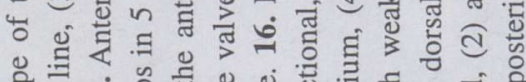

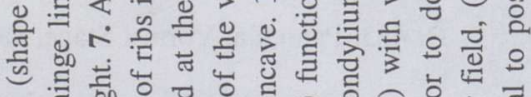
동

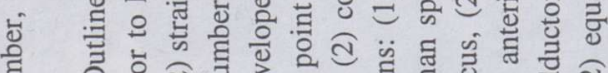
1)

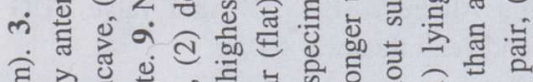

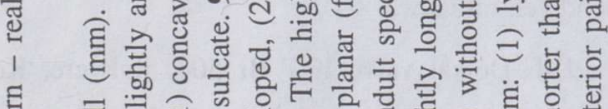

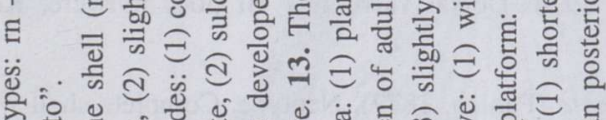
8.

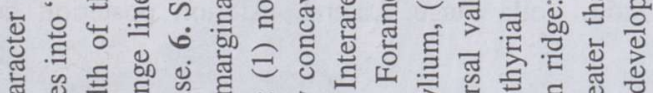

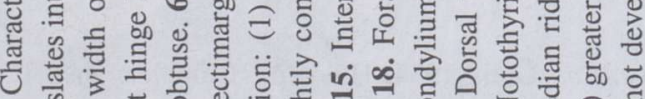

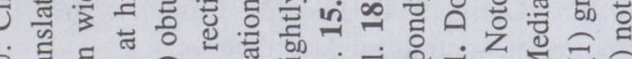

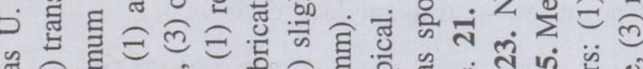

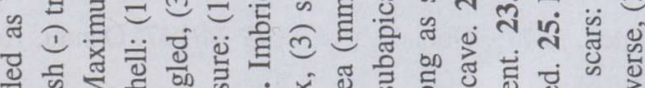

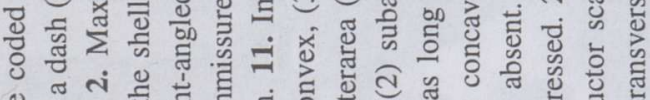
\%

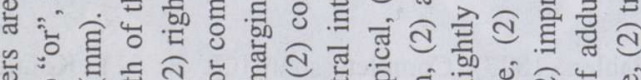

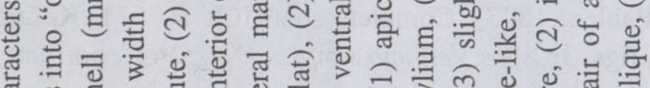

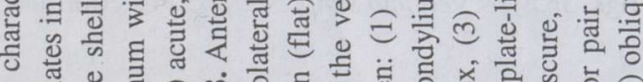

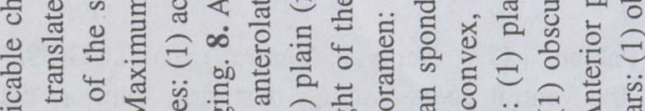

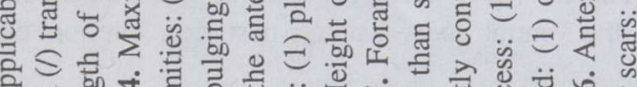

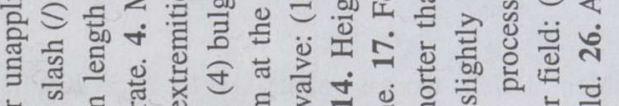

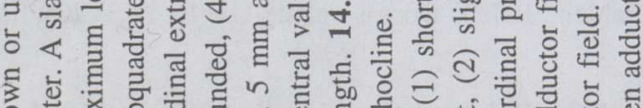

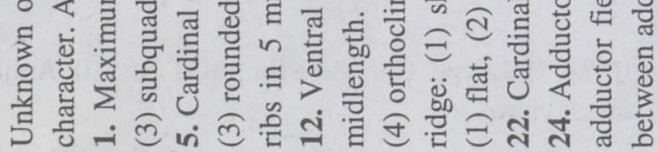




\section{PLATE I}

Figs. 1, 2, 5. Vellamo verneuilii (Eichwald, 1841). Neotype. Ventral valve IGT Br 477. Kõrgessaare, Vormsi Stage. Interior, exterior, and lateral views. Showing orthocline ventral interarea. The space under spondylium and the apical part of the spondylium are filled with the secondary shell material. $\times 1.5$.

Figs. 3, 4, 6, 9, 13. Vellamo verneuilii (Eichwald, 1841). Complete shell TUG 73/152. Kõrgessaare, Vormsi Stage. Lateral, anterior, ventral, posterior, and dorsal views. Showing subapical sealed foramen. $\times 1.5$.

Fig. 7. Vellamo verneuilii (Eichwald, 1841). Dorsal valve IGT Br 476. Sine loco. Interior view. Showing bulging anterior margin. $\times 1.5$.

Figs. 8, 10, 12. Vellamo verneuilii (Eichwald, 1841). Ventral valve IGT Br 925. Kõrgessaare, Vormsi Stage. Lateral, exterior, and interior views. Showing subapical sealed foramen and unusual subcircular outline. $\times 1.5$.

Fig. 11. Vellamo verneuilii (Eichwald, 1841). IGT Br 480. Kõrgessaare, Vormsi Stage. Dorsal valve, interior view. $\times 1.5$.

Figs. 14-16. Vellamo leigeri Öpik, 1934. IGT Br 483. Paluküla, Vormsi Stage. Dorsal and ventral valves. $\times 2$.

\section{PLATE II}

Figs. 1, 2, 4, 5. Vellamo praeemarginata Alichova, 1953. Ventral valve TUG 892/2. Aluvere, Haljala Stage. Interior, posterior, lateral, and ventral views. $\times 1.5$.

Figs. 3, 6. Vellamo ambisulcata Öpik, 1934. Dorsal valve IGT $\mathrm{Br}$ 504. Rakvere, Keila Stage. Interior and exterior views. $\times 1.5$.

Figs. 7, 10, 13, 16, 17. Vellamo emarginata (Pahlen, 1877). Neotype. Complete shell with several bryozoan colonies TUG 72/148. Oandu, Keila Stage. Lateral, exterior, posterior, dorsal, and anterior views. $\times 1.5$.

Figs. 8, 9, 11, 12, 14. Vellamo ambisulcata Öpik, 1934. Holotype. Complete shell IGT Br 502. Rakvere, Keila Stage. Dorsal, anterior, posterior, ventral, and lateral views. $\times 2$.

Figs. 15, 18. Vellamo emarginata (Pahlen, 1877). Dorsal valve TUG 74/147. Oandu, Keila Stage. Interior and exterior views. $\times 2$.

\section{PLATE III}

Figs. 1-4, 6. Vellamo pyramidalis (Pahlen, 1877). Complete shell IGT Br 511. Kohtla, Kukruse Stage. Figured by Öpik (1934, pl. 11, figs. 3a,b) as Vellamo simplex Öpik. Posterior, lateral, dorsal, anterior, and exterior views. $\times 4$.

Figs. 5, 7-10. Vellamo pyramidalis (Pahlen, 1877). Neotype. Ventral valve TUG 39/76. Kohtla, Kukruse Stage. Showing twisting of the ventral apex. Lateral, posterior, interior, exterior, and anterior views. $\times 4$.

Figs. 11, 13. Vellamo pyramidalis (Pahlen, 1877). Dorsal valve IGT Br 513. Kohtla, Kukruse Stage. Exterior and interior views. $\times 3$.

Figs. 12, 14-16. Vellamo anijana Öpik, 1934. Holotype. Complete shell IGT Br 510. Anija, Haljala Stage. Posterior, exterior, anterior, and dorsal views. $\times 3$. 


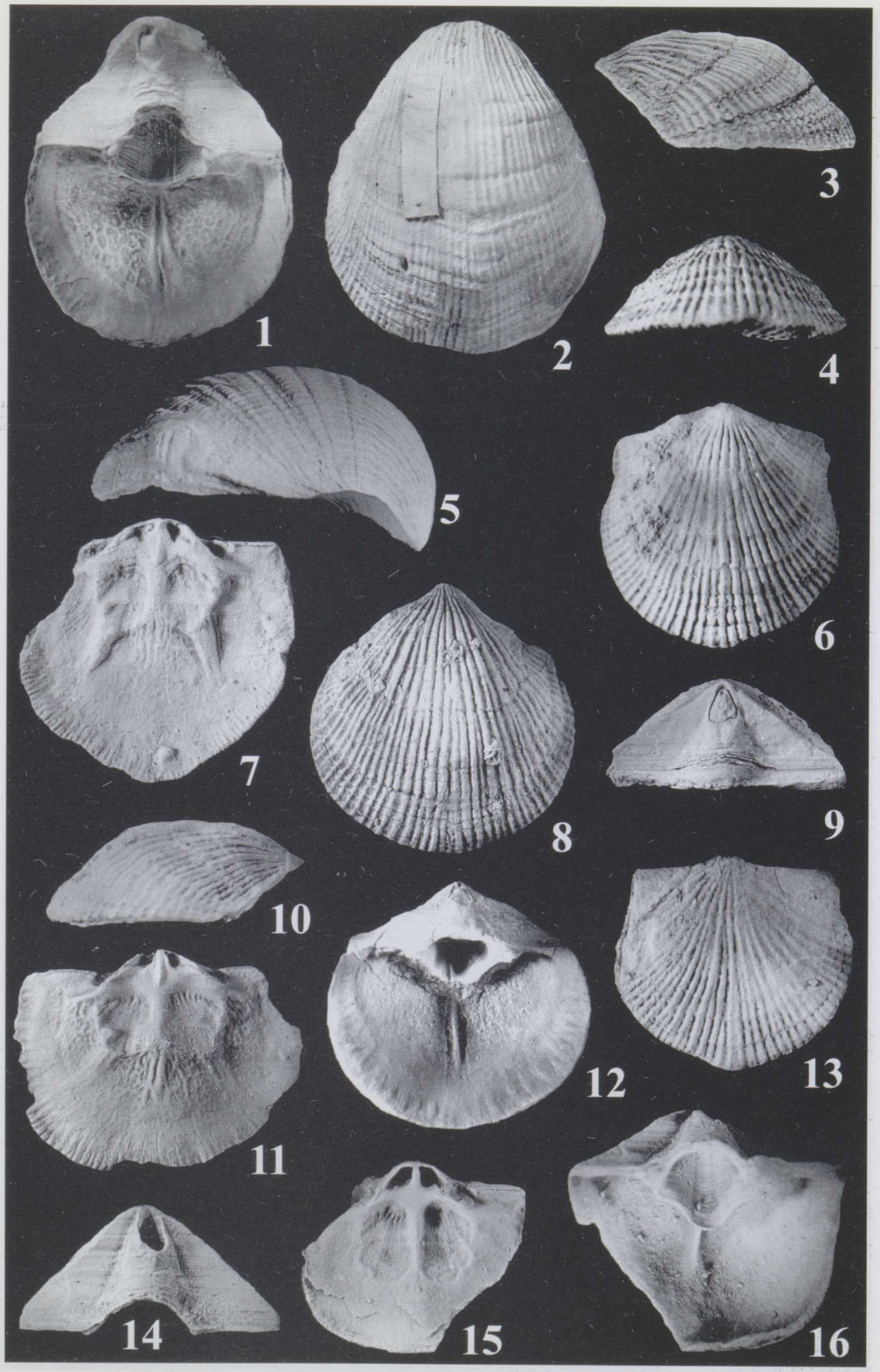




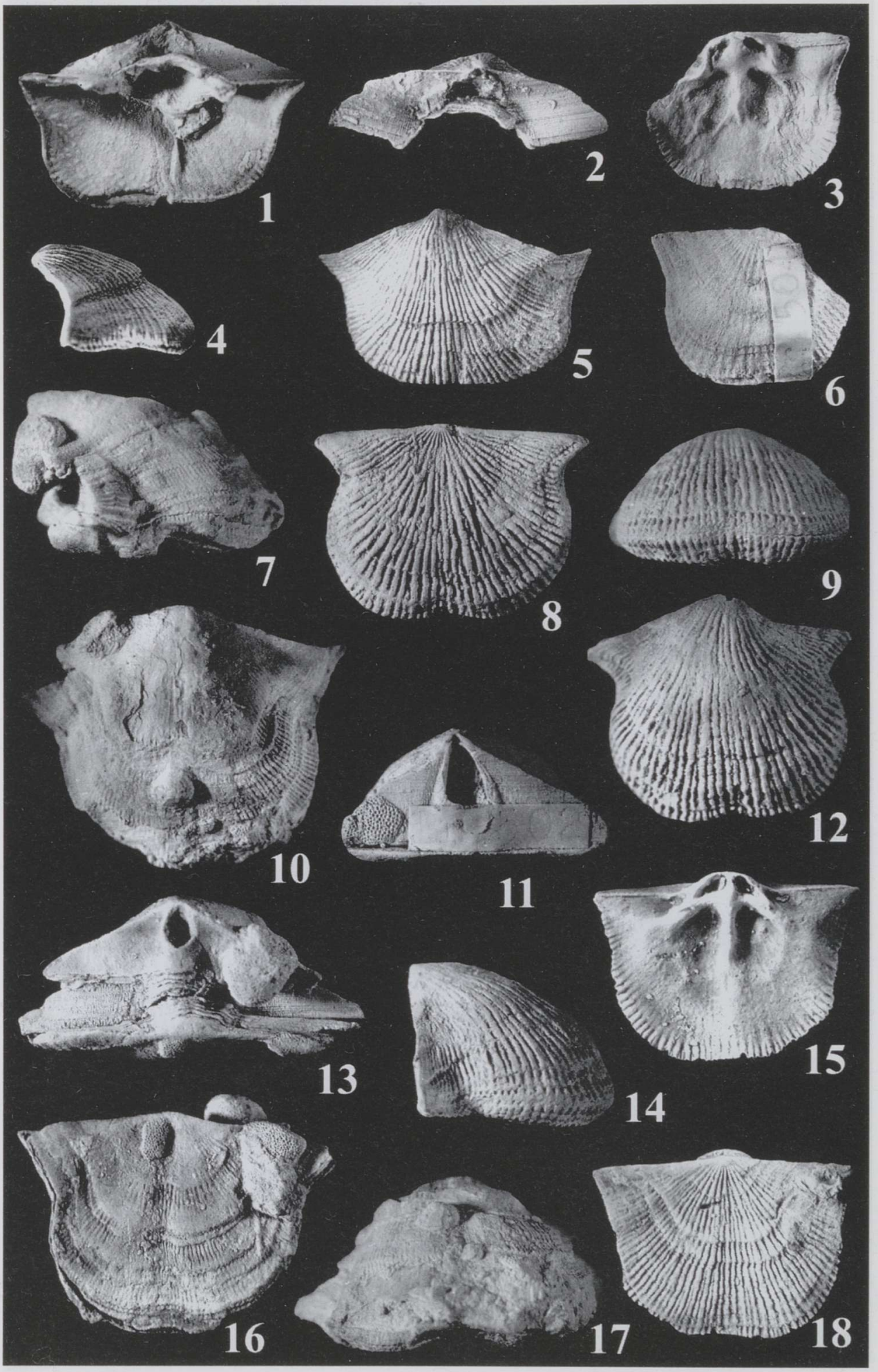




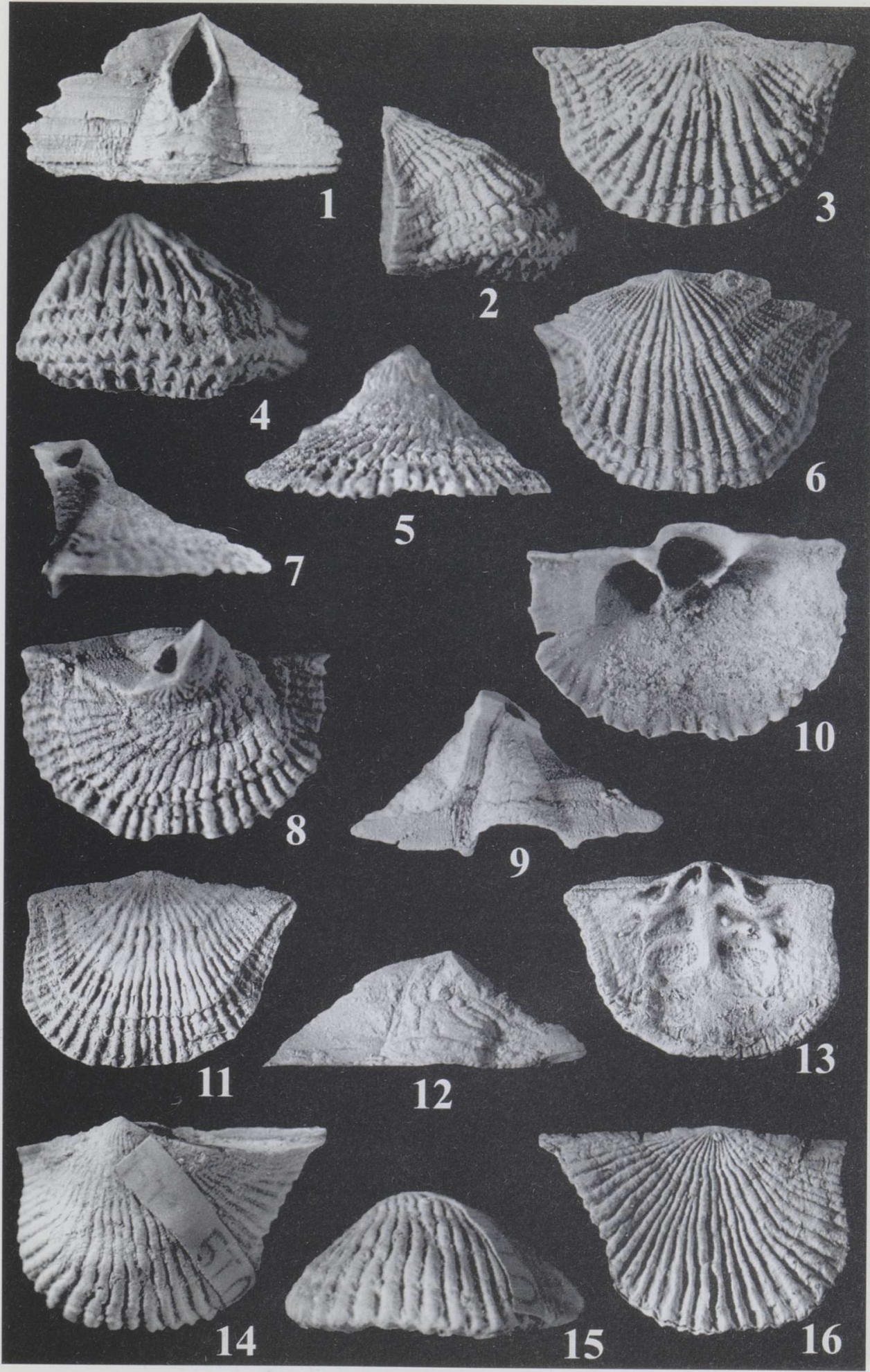




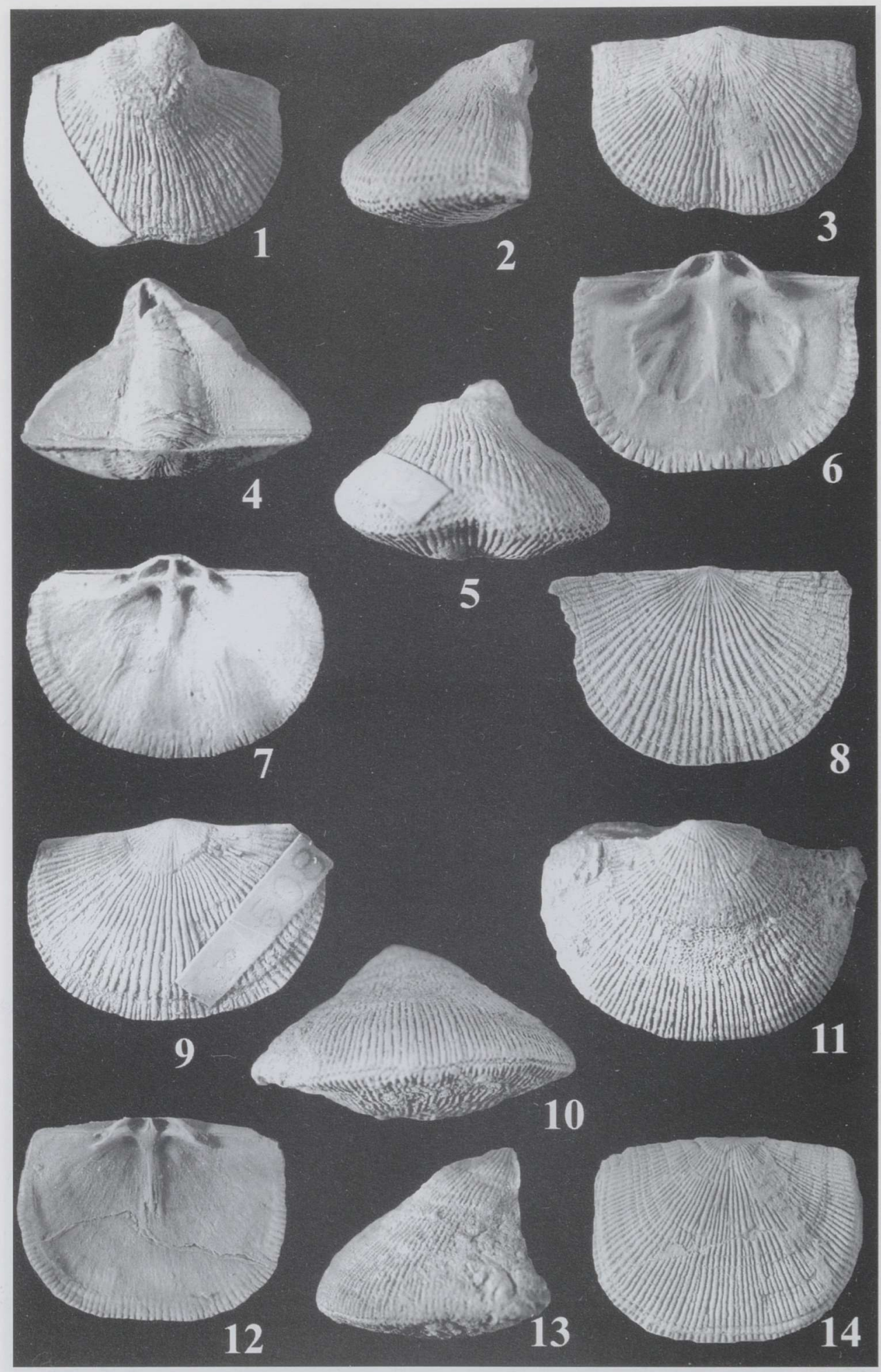




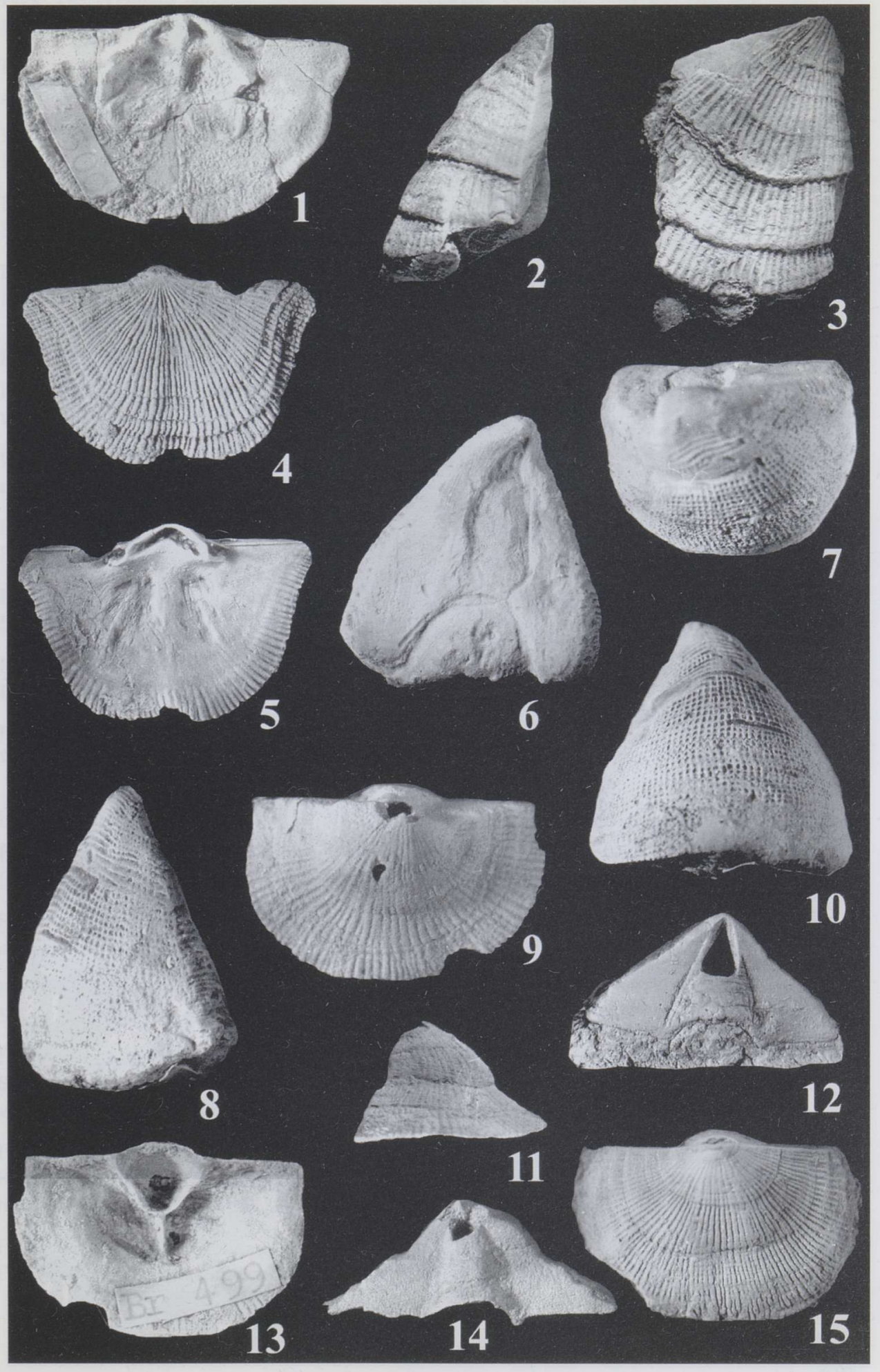




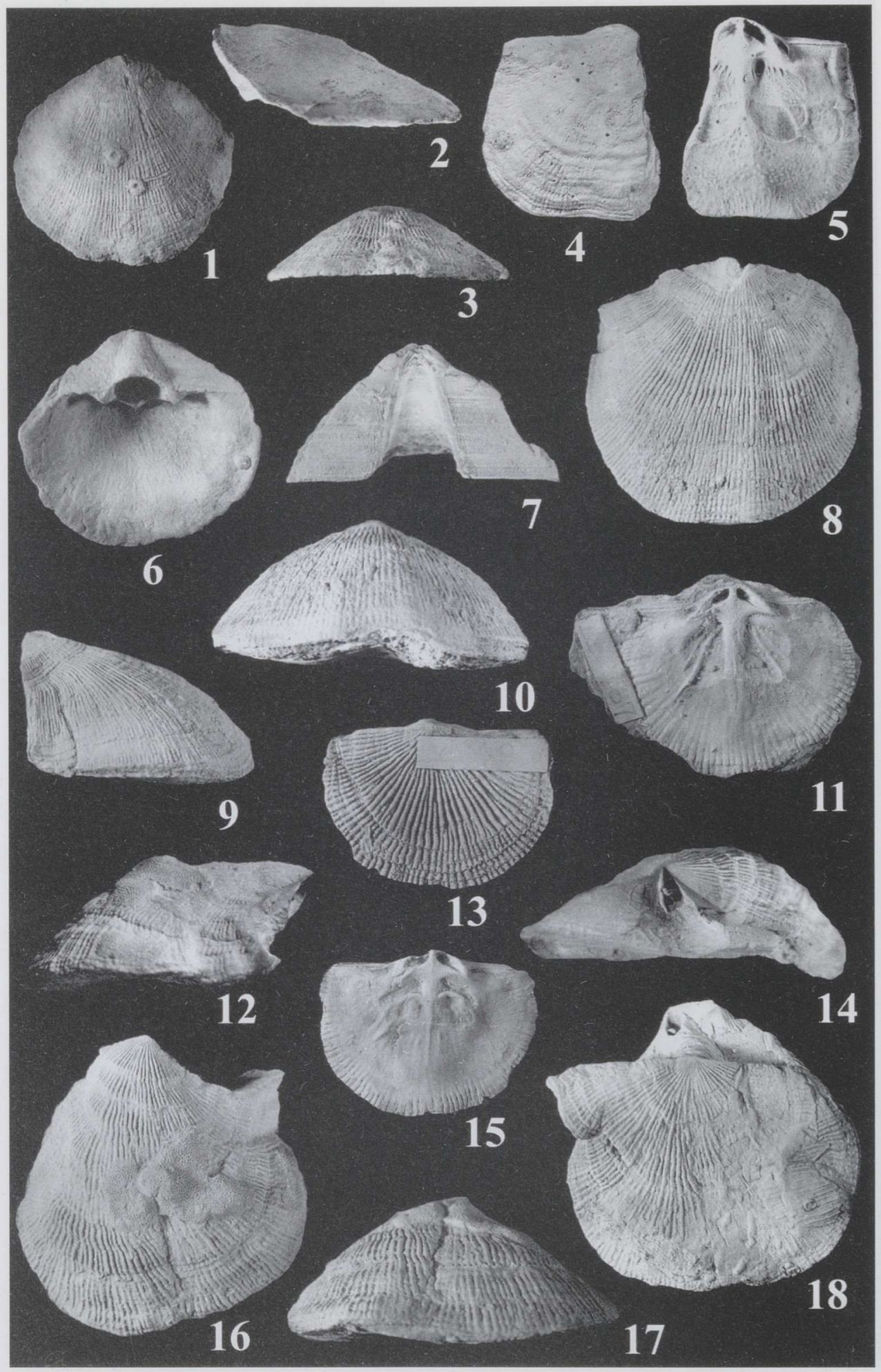




\section{PLATE IV}

Figs. 1-5. Vellamo oandoensis Öpik, 1934. Holotype. Complete shell IGT Br 505. Sine loco, Oandu Stage. Exterior, posterior, lateral, dorsal, and anterior views. $\times 2$.

Figs. 6, 8. Vellamo oandoensis Öpik, 1934. Dorsal valve IGT Br 923. Saku, Oandu Stage. A gerontic specimen showing adductor scars. Interior and exterior views. $\times 2$.

Figs. 7, 9. Vellamo oandoensis Öpik, 1934. Dorsal valve IGT Br 508. Rakvere, Oandu Stage. Interior and exterior views. $\times 2$.

Figs. 10, 11, 13. Vellamo parva Öpik, 1930. Complete shell TUG 56/26. Harku, Kukruse Stage. Exterior, anterior, and lateral views. $\times 2$.

Figs. 12, 14. Vellamo parva Öpik, 1930. Dorsal valve IGT Br 516. Figured by Öpik (1934, pl. 11, figs. 1a,b) as V. rara Öpik. Interior and exterior views. $\times 2$.

\section{PLATE V}

Fig. 1. Vellamo silurica Öpik, 1934. Dorsal valve IGT Br 500. Porkuni, Porkuni Stage. Interior view. $\times 2$.

Figs. 2, 3. Vellamo cf. phrygia Öpik, 1934. Ventral valve TUG 77/15. Oandu, Keila Stage. Lateral and exterior views. $\times 2$.

Figs. 4, 5. Vellamo defecta Öpik, 1934. Holotype. Dorsal valve IGT Br 501. Vasalemma, Oandu Stage. Interior and exterior views. $\times 2$.

Figs. 6-8, 10. Vellamo phrygia Öpik, 1934. Holotype. Ventral valve IGT Br 486. Saue, Keila Stage. Posterior, exterior, anterior, and lateral views. $\times 2$.

Figs. 9, 11, 13, 14. Vellamo silurica Öpik, 1934. Holotype. Ventral valve IGT Br 499. Porkuni, Porkuni Stage. Exterior, lateral, interior, and posterior views. $\times 1.5$.

Figs. 12, 15. Vellamo symmetrica Öpik, 1934. Holotype. Ventral valve IGT Br 484. Paluküla, Vormsi Stage. Posterior and exterior views. $\times 1.5$.

\section{PLATE VI}

Figs. 1-3, 6. Vellamo aenigma Öpik, 1934. Ventral valve TUG 892/1. Vaardi, Pirgu Stage. Exterior, lateral, posterior, and interior views. Natural size.

Figs. 4, 5. Vellamo magna Öpik, 1934. Dorsal valve TUG 72/60. Rakvere, Keila Stage. Exterior and interior views. Natural size.

Figs. 7-10. Vellamo magna Öpik, 1934. Holotype. Ventral valve IGT Br 496. Rakvere, Keila Stage. Posterior, exterior, lateral, and anterior views. $\times 1.2$.

Fig. 11. Vellamo wesenbergiensis (Pahlen, 1877). Dorsal valve IGT Br 487. Rägavere, Rakvere Stage. Figured by Öpik (1934, pl. 10, fig. 7) as Vellamo wesenbergensis auriculata Öpik. Interior view. Showing strong radial ridges on the interior of the adductor scars. $\times 1.2$.

Figs. 13, 15. Vellamo wesenbergiensis (Pahlen, 1877). Dorsal valve IGT $\mathrm{Br}$ 493. Rägavere, Rakvere Stage. Showing unusual pattern of adductor scars consisting of radial and transverse ridges. $\times 1.2$.

Figs. 12, 14, 16-18. Vellamo wesenbergiensis (Pahlen, 1877). Neotype. Complete shell IGT $\mathrm{Br}$ 494. Rägavere, Rakvere Stage. $\times 1.2$. 
Alikhova (1953) described a new species, Vellamo praeemarginata. She explained remarkable variability and asymmetry of $V$. wesenbergensis with ecological reasons. Nasedkina (1970) mentioned numerous Vellamo species from the western slope of the North and Middle Urals, among them three new species and one new subspecies. Species of Vellamo were also described by Bondarev (1968) and Oradovskaya (1977).

Vellamo species from the British Isles have been reviewed and described by Williams (1963), Wright (1964), Mitchell (1977), Cocks (1978), Hiller (1980), and Harper (1989). American species have been described by Raymond (1921), Twenhofel (1927), Wilson (1946), and Bolton (1961). Rare specimens have been reported from Algeria (Termier \& Termier, 1950), Belgium (Sheehan, 1987), and Tasmania (Laurie, 1991).

\section{SYSTEMATIC DESCRIPTIONS}

Superfamily CLITAMBONITOIDEA Winchell \& Schuchert, 1893

Family CLITAMBONITIDAE Winchell \& Schuchert, 1893

Genus Vellamo Öpik, 1930, emend.

1930a Clitambonites (Vellamo) n. subg.; Öpik, p. 212.

1932 Vellamo Öpik; Shuchert \& Cooper, p. 114.

1934 Vellamo Öpik; Öpik, p. 98.

1953 Vellamo Öpik; Alikhova, p. 78.

1955 Vellamo Öpik; Schimer \& Schrock, p. 297.

1965 Vellamo Öpik; Williams \& Wright, p. H352.

1970 Vellamo Öpik; Nasedkina, p. 43.

1973 Vellamo Öpik; Nasedkina, p. 124.

Type species. Orthis verneuilii Eichwald, 1841; p. 5, pl. 2, figs. 3-5.

Diagnosis. Shell up to $32 \mathrm{~mm}$ wide and up to $40 \mathrm{~mm}$ long, planoconvex to ventribiconvex. Outline transversely semiovate to semicircular, subquadrate or blazon-like. Maximum width at hinge line or anterior to hinge line. Anterior margin rounded to emarginate (B-shaped), anterior commissure slightly sulcate or rectimarginate. Ornamentation costellate, ribs mostly of equal size. Concentric growth lines occasionally visible, imbrication developed at the anterior part of the ventral valve, or rarely, all over the exterior surface.

Ventral valve often asymmetrical, either due to distorted growth or twisted apex. Ventral interarea up to $25 \mathrm{~mm}$ high, catacline to apsacline, rarely procline with flat, concave or irregularly terraced profile. Delthyrium about one-third as wide as hinge line, closed by convex deltidium. Deltidium perforated by large foramen, sealed during lifetime in some species. 
Dorsal valve flat or slightly convex. Dorsal interarea short, anacline, notothyrium closed by well-developed chilidium. Notothyrial cavity divided by simple ridge-like cardinal process. Dorsal adductor field quadripartite with the anterior and posterior pairs separated by a clearly defined ridge perpendicular to the median ridge. Commonly the scars are of equal size or the anterior pair is smaller than the posterior pair. Some species show poorly defined adductor fields.

Shell substance impunctate.

Discussion. Bondarev (1968, p. 71) diagnosed Vellamo (?) summa as a species with pseudopunctate shell substance. His description of pseudopunctation that "can be recognized on the outer layer of the shell near the anterolateral margin, where on the surface of the ribs small circular holes are radially disposed" is a perfect diagnosis for aditicules, a type of exopunctae that accommodated setal bristles and are a part of the sensory system of brachiopods (Wright, 1981). In fact, aditicules are passing through the entire shell, but can normally be seen only near the shell margin as they get sealed inside the shell and are therefore visible only at the outer surface of the shell. Wright \& Rubel (1996) figured several species of Kullervo Öpik, 1932, possessing aditicules, and mentioned their absence as a generic character in Apomatella Schuchert \& Cooper, 1931. The present study does not attribute a diagnostic value to the absence or presence of aditicules, due to their sporadic occurrence. They are better preserved and exposed in specimens showing imbricative sculpture at the anterolateral part of the shell.

Species assigned apart from the species described below:

Vellamo diconvexa Nasedkina, 1970 (Nasedkina, pp. 46-47, figs. 5-7; pl. 9, fig. 7).

Orthisina diversa Shaler, 1865 (Shaler, p. 67).

Skenidium Grayiae Davidson, 1883 (Davidson, p. 175, pl. 11, figs. 3-9).

Vellamo mitra Nasedkina, 1970 (Nasedkina, pp. 49-50, pl. 9, figs. 1-4).

Vellamo praeemarginata grandis Nasedkina, 1970 (Nasedkina, pp. 44-45, pl. 8, figs. 1-4).

Vellamo putukuneiensis Oradovskaya, 1977 (Oradovskaya, pp. 91-93, pl. 3, figs. 5-7). Skenidium? Shallockiense Davidson, 1883 (Davidson, p. 174, pl. 11, figs. 6, 7.)

Vellamo sinclairi Wilson, 1946 (Wilson, p. 115, pl. 3, fig. 30).

Vellamo sulculata Wright, 1964 (Wright, pp. 236-240, pl. 10, figs. 1, 2, 4, 5, 8, 9 , $11,12,14)$.

Vellamo (?) summa Bondarev, 1968 (Bondarev, p. 71; pl. 4, figs. 9-13; pl. 5, figs. 1-4).

Clitambonites trentonensis Raymond, 1921 (Raymond, p. 27, pl. 7, figs. 6, 7). Vellamo typylica Nasedkina, 1970 (Nasedkina, pp. 47-49, pl. 8, figs. 8, 9).

Vellamo sp. (Laurie, 1991, p. 49, fig. 35c).

Vellamo sp. (Mitchell, 1977, p. 65, pl. 11, figs. 17, 18).

Vellamo sp. (Sheehan, 1987, p. 28, pl. 7, figs. 21-23).

Vellamo sp. (Termier \& Termier, 1950, p. 18, pl. 2, figs. 4-6).

Vellamo sp. (Williams, 1963 , p. 428 , pl. 10, figs. 14,18 ).

Vellamo sp. (Wright, 1964, p. 241, pl. 10, figs. 6, 7). 
Species rejected. Vellamo chinensis (Weller).

The specimen figured as Vellamo chinensis (Weller) (Fu, 1982) is well preserved, small, with fine costellate ornamentation, convex ventral and slightly convex dorsal valve. All the studied Vellamo species have a big deltidium, about $1 / 3$ of the length of the hinge line, but the deltidium of the figured specimen is considerably smaller. The figured specimen lacks foramen and belongs more likely to the genus Eremotoechia Cooper, 1956.

Occurrence. Middle and Upper Ordovician. Belgium, British Isles, East Baltic and Podolia, western slope of the Ural Mountains and the Vaigach Island, Northeast Asia, eastern North America, Tasmania, Algeria.

Vellamo verneuilii (Eichwald, 1841)

Plate I, figures 1-13

1841 Orthis verneuilii Eichwald, p. 51, pl. 2, figs. 3-5.

1845 Orthis verneuilii Eichwald; Murchison et al., vol. 2, p. 201, pl. 11, fig. 8; pl. 12, fig. 1.

1877 Orthisina verneuilii Eichwald; Pahlen, p. 35, pl. 4, figs. 4-6, 11-15.

1930b Clitambonites (Vellamo) verneuili (Eichwald); Öpik, p. 212.

1934 Vellamo verneuili (Eichwald); Öpik, p. 100, pl. 13, figs. 1, 4; pl. 14, figs. $1-7 b$.

1934 Vellamo sauramoi n. sp.; Öpik, pl. 13, figs. 8, 8a,b.

1976 Vellamo verneuili (Eichwald); Tsegelnyuk, pp. 44-46, pl. 5, fig. 14; pl. 6, fig. 1.

non 1973 Vellamo cf. verneuili (Eichwald); Nasedkina, pp. 125-126, pl. 22, figs. 9-12.

Neotype. Ventral valve IGT Br 477; Vormsi Stage, Kõrgessaare, Estonia. Pl. I, figs. 1, 2, 5 .

Material. 140 ventral valves, 61 dorsal valves, 64 complete shells.

Diagnosis. Shell up to $32 \mathrm{~mm}$ long and up to $35 \mathrm{~mm}$ wide; semiovate, semicircular, or subquadrate. Maximum width of the shell at hinge line to slightly anterior to midlength, cardinal extremities acute to obtuse, sides concave to straight, anterior margin straight to bulging, anterior commissure rectimarginate. Number of ribs 6-9 in $5 \mathrm{~mm}$ at $5 \mathrm{~mm}$ from ventral beak, 5-7 at the anterolateral margin. Lateral profile of the ventral valve convex, the highest point at apex to at midlength. Ventral interarea up to $17 \mathrm{~mm}$ high, planar to concave, apsacline to orthocline. Foramen subapical, sealed. Spondylium simplex supported by ridge extending to anterior margin. Dorsal valve flat to slightly concave, without sulcus or with weak sulcus. 
Discussion. Öpik (1934) described a single medium-size specimen from Vormsi, Vormsi Stage, as V. sauramoi. The specimen shows subquadrate outline, a nearly straight anterior margin, straight sides, and flat lateral profile. Its foramen is sealed and the ornamentation is coarse. Obviously the specimen described as $V$. sauramo $i$ is a juvenile specimen of $V$. verneuilii.

Occurrence. Nabala, Vormsi, and Pirgu stages. Haapsalu, Kõrgessaare, Moe, Paluküla, Paopää, Saxby, Tapa, Torma, Uuemõisa, and Voore outcrops. Ingria (Alikhova, 1953).

\section{Vellamo leigeri Öpik, 1934 \\ Plate I, figures 14-16}

1934 Vellamo leigeri n. sp.; Öpik, pp. 105-106, pl. 12, figs. 5-5c.

Holotype. Dorsal and ventral valves IGT $\mathrm{Br} 483$; Vormsi Stage, Paluküla, Estonia.

Remarks. V. leigeri occurs in the Vormsi Stage together with V. verneuilii. It differs from the latter in finer ornamentation. Specimens of $V$. verneuilii with a width of $20 \mathrm{~mm}$ show a sealed foramen. The single specimen of V. leigeri possesses open foramen and thin shell, not common in $V$. verneuilii.

Vellamo praeemarginata Alichova, 1953

Plate II, figures 1, 2, 4, 5

1953 Vellamo praeemarginata n. sp.; Alikhova, pp. 79-80, pl. 10, fig. 12.

Holotype. Ventral valve from the Idavere Stage, St Petersburg region. Kept in the private collection of Alikhova.

Material. 19 ventral valves, 4 dorsal valves.

Diagnosis. Shell up to $15 \mathrm{~mm}$ long and up to $22 \mathrm{~mm}$ wide, semiovate to subquadrate. Maximum width of the shell at hinge line to slightly anterior to midlength, cardinal extremities acute, sides concave, anterior margin emarginate, anterior commissure rectimarginate to sulcate. Number of ribs $9-12$ in $5 \mathrm{~mm}$ at $5 \mathrm{~mm}$ from ventral beak, 7-8 at the anterolateral margin. Ventral interarea up to $8 \mathrm{~mm}$ high, planar to concave, catacline to apsacline. Dorsal valve flat, with median sulcus.

Discussion. $V$. praeemarginata is a close species to $V$. pyramidalis. It differs from the latter in a slightly bigger shell and finer ornamentation.

Occurrence. Haljala Stage. Idavere and Aluvere outcrops. Ingria (Alikhova, 1953). 
1934 Vellamo ambisulcata n. sp.; Öpik, p. 112, pl. 12, figs. 9a-c.

Holotype. Conjoined valves IGT Br 502; Keila Stage, Rakvere, northern Estonia. Material. 4 complete shells, 10 ventral valves, 9 dorsal valves.

Diagnosis. Shell up to $15 \mathrm{~mm}$ long and up to $21 \mathrm{~mm}$ wide, semiovate to subquadrate. Maximum width of the shell at hinge line, cardinal extremities acute, sides concave, anterior margin emarginate, anterior commissure rectimarginate to sulcate. Number of ribs $8-9$ in $5 \mathrm{~mm}$ at $5 \mathrm{~mm}$ from ventral beak, 5-8 at the anterolateral margin. Lateral profile of the ventral valve plain to convex, the highest point at apex. Ventral interarea up to $9 \mathrm{~mm}$ high, planar to concave, catacline to apsacline. Dorsal valve flat to slightly convex, without sulcus or with weak sulcus. Notothyrial platform lying anterior to dorsal interarea.

Discussion. V. ambisulcata is one of the four species of Vellamo found in the Keila Stage. V. ambisulcata resembles $V$. emarginata in having acute cardinal angles, concave sides, and emarginate anterior margin, differing in the interior morphology of the dorsal valve. The notothyrial platform which in most species of Vellamo lies almost flush with the hinge line has been dispositioned anteriorly to the hinge line in this species. V.ambisulcata shows coarser ribbing than V. emarginata.

Occurrence. Keila Stage. Jälgimäe, Oandu, Rakvere, and Saku outcrops. Core sections: Kuusiku - 15.75-15.80 m; Saku - 13.42-13.47 m; Tuula - 11.2 m, and Voore $-16.05 \mathrm{~m}$.

Vellamo emarginata (Pahlen, 1877)

Plate II, figures $7,10,13,15-18$

1877 Orthisina emarginata n. sp.; Pahlen, p. 38, pl. 4, figs. 16-18.

1934 Vellamo emarginata (Pahlen); Öpik, pp. 110-111, pl. 12, figs. 4-6.

1953 Vellamo emarginata (Pahlen); Alikhova, pp. 80-82, pl. 10, figs. 1-3.

Type. Pahlen (1877) did not select the holotype. His collections were partly destroyed during World War II, partly distributed to several schools in Estonia after the war. The part housed in the Museum of the Natural History in Tallinn does not contain any specimens belonging to the genus Vellamo. The specimen kept in the museum under the number $1201 \mathrm{G1:404}$ resembles V. emarginata figured on the drawing by Pahlen (1877, pl. 4, figs. 16-18) but its origin and locality are unknown.

Neotype. Complete shell TUG 72/148; Keila Stage, Oandu, Estonia.

Material. 20 complete shells, 24 ventral valves, 7 dorsal valves. 
Diagnosis. Shell up to $22 \mathrm{~mm}$ long and up to $28 \mathrm{~mm}$ wide, semiovate to subquadrate. Maximum width of the shell at hinge line or slightly anterior to midlength, cardinal extremities acute, sides concave, anterior margin emarginate, anterior commissure rectimarginate to sulcate. Number of ribs $10-11$ in $5 \mathrm{~mm}$ at $5 \mathrm{~mm}$ from ventral beak, 10-11 at the anterolateral margin. Lateral profile of the ventral valve plain to convex, the highest point at apex to slightly anterior to apex. Ventral interarea up to $12 \mathrm{~mm}$ high, planar to concave, apsacline. Dorsal valve flat to slightly convex, without sulcus or with weak sulcus. Notothyrial platform lying anterior to hinge line.

Discussion. V. emarginata resembles $V$. ambisulcata. V. emarginata is bigger, shows finer ornamentation than $V$. ambisulcata and the maximum width of the adult shell is slightly anterior to midlength.

Occurrence. Haljala and Keila stages. Allika, Aluvere, Aru, Kurtna, Oandu, Pääsküla, Rakvere, Saku, Sompa, and Sõmeru outcrops.

\section{Vellamo pyramidalis (Pahlen, 1877)}

Plate III, figures $1-11,13$

1877 Orthisina pyramidalis n. sp.; Pahlen, p. 39, pl. 4, figs. 19-21.

1930a Clitambonites (Vellamo) pyramidalis (Pahlen); Öpik, p. 213, pl. 19, figs. 220-222, 225, 226.

1930a Clitambonites (Vellamo) pyramidalis arcuatus n. subsp.; Öpik, p. 215, pl. 19, fig. 223.

1930a Clitambonites (Vellamo) pyramidalis pahleni n. subsp.; Öpik, p. 216, pl. 19, fig. 224.

1930a Clitambonites (Vellamo) pyramidalis simplex n. subsp.; Öpik, p. 217, pl. 19, figs. 219, 227.

1930 b Clitambonites (Vellamo) viruanus n. sp.; Öpik, p. 15-16, pl. 2, figs. 14a-c.

1934 Vellamo simplex A. Ö.; Öpik, p. 115, pl. 11, figs. 3a,b.

1934 Vellamo pyramidalis (Pahlen); Öpik, p. 115, pl. 11, figs. 4, 5.

Neotype. Ventral valve TUG 39/76; Kukruse Stage, Kohtla, Estonia.

Material. 11 complete shells, 67 ventral valves, 26 dorsal valves.

Diagnosis. Shell up to $9 \mathrm{~mm}$ long and up to $16 \mathrm{~mm}$ wide, semiovate to subquadrate. Maximum width of the shell at hinge line, cardinal extremities acute, sides concave to straight, anterior margin emarginate to rounded, anterior commissure rectimarginate to sulcate. Number of ribs 7-10 in $5 \mathrm{~mm}$ at $5 \mathrm{~mm}$ from ventral beak, 6-10 at the anterolateral margin. Ventral interarea up to $8 \mathrm{~mm}$ high, planar to concave, catacline to apsacline. Dorsal valve flat, with median sulcus. Anterior pair of adductor scars larger than posterior pair or equal to posterior pair.

Discussion. Öpik (1930a, 1934) described V. pyramidalis as being distinct from $V$. simplex, also two subspecies were described. The present study regards them as 
intraspecific varieties. $V$. pyramidalis pahleni and $V$. pyramidalis arcuatus should be treated as juvenile specimens. $V$. simplex does not show remarkable differences from $V$. pyramidalis. $V$. pyramidalis occurs in the same stages with $V$. parva. It is distinguished from the latter by coarser ornamentation, smaller shell, and acute cardinal angles.

Occurrence. Lasnamägi, Uhaku, Kukruse, and Haljala stages. Allika, Harku, Kohtla, Kostivere, Küttejõud, Lasnamägi, Purtse, and Uhaku outcrops.

\section{Vellamo anijana Öpik, 1934 \\ Plate III, figures $12,14-16$}

1934 Vellamo anijana n. sp.; Öpik, pp. 114-115, pl. 12, fig. 10.

Holotype. Complete shell IGT Br 510; Haljala Stage, Anija, northern Estonia.

Material. 2 complete shells, 7 ventral valves, 1 dorsal valve.

Diagnosis. Shell up to $16 \mathrm{~mm}$ long and up to $19 \mathrm{~mm}$ wide, semiovate to subquadrate. Maximum width of the shell at hinge line, cardinal extremities acute, sides concave, anterior margin emarginate to straight, anterior commissure sulcate. Number of ribs 5-7 in $5 \mathrm{~mm}$ at $5 \mathrm{~mm}$ from ventral beak, 7-8 at the anterolateral margin. Lateral profile of the ventral valve convex, the highest point at apex to slightly anterior to apex. Ventral interarea up to $8 \mathrm{~mm}$ high, planar to concave, catacline to apsacline. Dorsal valve flat, with weak sulcus.

Discussion. $V$. anijana occurs in the Haljala Stage together with $V$. praeemarginata and $V$. emarginata, differing in coarser ornamentation. In shape and outline similar to adult $V$. pyramidalis, but the ventral valve of $V$. anijana is more convex with the highest point of the valve anterior to the apex.

Occurrence. Haljala Stage. Allika, Anija, Harku, Sõjamägi, and Soonurme outcrops.

\section{Vellamo oandoensis Öpik, 1934}

$$
\text { Plate IV, figures 1-9 }
$$

1934 Vellamo oandoensis n. sp.; Öpik, pp. 113-114, pl. 12, figs. 11a-14.

Holotype. Complete shell IGT Br 505; Oandu Stage, Rakvere, northern Estonia.

Material. 15 complete shells, 68 ventral valves, 35 dorsal valves.

Diagnosis. Shell up to $17 \mathrm{~mm}$ long and up to $27 \mathrm{~mm}$ wide, subquadrate. Maximum width of the shell at hinge line to slightly anterior to midlength, cardinal extremities right-angled to obtuse, sides straight, anterior margin emarginate to straight. Number of ribs $8-9$ in $5 \mathrm{~mm}$ at $5 \mathrm{~mm}$ from ventral beak, $8-11$ at the anterolateral margin. Lateral profile of the ventral valve plain to convex, the 
highest point at apex. Ventral interarea up to $13 \mathrm{~mm}$ high, planar, procline to apsacline. Dorsal valve flat to slightly convex, with median sulcus. Dorsal adductor field obscure.

Discussion. $V$. oandoensis differs from other species of the Keila and Oandu stages in subquadrate outline, straight sides, and thin shell. The dorsal adductor field is usually poorly defined, only gerontic specimens show typical adductor scars.

Occurrence. Keila and Oandu stages. Rakvere, Oandu, Jälgimäe, Tõrremäe, Saku, and Vasalemma outcrops. Core sections: Vasalemma - $3.15 \mathrm{~m}$; Kaasiku - $16.95 \mathrm{~m}$.

\section{Vellamo parva Öpik, 1930 \\ Plate IV, figures 10-14}

1930a Clitambonites (Vellamo) parvus n. sp.; Öpik, p. 219, pl. 21, fig. 279.

1930a Clitambonites (Vellamo) ultimus n. sp.; Öpik, p. 219, pl. 22, fig. 280.

1934 Vellamo parva A. Öpik; Öpik, p. 116, pl. 11, figs. 2a,b.

1934 Vellamo rara n. sp.; Öpik, p. 116, pl. 2, figs. 5a,b; pl. 11, figs. 1a,b.

Holotype. Dorsal valve IGT Br 300 (No. 279); Keila Stage, Kohtla, Estonia.

Material. 8 complete shells, 17 ventral valves, 9 dorsal valves.

Diagnosis. Shell up to $23 \mathrm{~mm}$ long and up to $21 \mathrm{~mm}$ wide, semiovate to subquadrate. Maximum width of the shell at hinge line to slightly anterior to midlength, cardinal extremities right-angled to obtuse, sides straight, anterior margin straight to rounded, anterior commissure rectimarginate. Number of ribs 9-15 in $5 \mathrm{~mm}$ at $5 \mathrm{~mm}$ from ventral beak, $14-17$ at the anterolateral margin. Lateral profile of the ventral valve convex, the highest point at apex to slightly anterior to apex. Ventral interarea up to $9 \mathrm{~mm}$ high, planar to concave, catacline to apsacline. Dorsal valve slightly convex, without sulcus or with weak sulcus. Dorsal adductor field obscure.

Discussion. Öpik (1930a, 1934) described three different species - V. ultimus, $V$. parva, and $V$. rara. The present study regards them in the limits of intraspecific variability. V. parva, figured by Öpik in 1930a (pl. 21, fig. 279), is a juvenile specimen. The dorsal valves of V. rara (figured by Öpik, 1934; pl. 11, figs. 1a,b) and $V$. ultimus (figured by Öpik, 1930a; pl. 22, fig. 280) show similar internal and external features. Deciding by the acute cardinal angles, the specimen figured as $V$. ultimus is slightly younger than the specimen figured as V.rara. Also V. ultimus Öpik shows slight sulcus on the dorsal valve, but the dorsal valve of V. rara Öpik is flat. The outline of both specimens is subquadrate, the ornamentation is fine and the adductor field is oblique. These are also the main characters distinguishing $V$. parva from $V$. pyramidalis, as they both occur in the same stages.

Occurrence. Lasnamägi, Uhaku, Kukruse, and Haljala stages. Kohtla, Allika, Harku, Humala, Sõjamägi, Lasnamägi, and Kostivere outcrops. 
1934 Vellamo silurica n. sp.; Öpik, p. 111, pl. 12, figs. 1a,b, 2.

Holotype. Ventral valve IGT Br 499; Porkuni Stage, Porkuni, Estonia.

Remarks. The shape and size of the ventral valve of $V$. silurica are similar to those of $V$. symmetrica. The main difference lies in the ornamentation. $V$. silurica shows coarser ornamentation than $V$. symmetrica.

\section{Vellamo defecta Öpik, 1934 \\ Plate V, figures 4,5}

1934 Vellamo defecta n. sp.; Öpik, pp. 111-112, pl. 12, figs. 3a,b.

Holotype. Dorsal valve IGT Br 501; Oandu Stage, Vasalemma, northern Estonia. Remarks. $V$. defecta occurs in the Oandu Stage together with $V$. oandoensis. It differs from the latter in the semiovate shell shape, acute cardinal extermities, and concave sides. It is the only species in the genus without cardinal process.

\section{Vellamo phrygia Öpik, 1934 \\ Plate $\mathrm{V}$, figures $2,3,6-8,10$}

1934 Vellamo phrygia n. sp.; Öpik, p. 107, pl. 12, figs. 6, 7.

Holotype. Ventral valve IGT Br. 486; Keila Stage, Saue, Estonia.

Material. 4 ventral valves.

Diagnosis. Shell up to $18 \mathrm{~mm}$ long, $24 \mathrm{~mm}$ wide, semiovate to semicircular. Maximum width of the shell at hinge line to slightly anterior to hinge line, cardinal extremities acute to obtuse, anterior margin rounded, anterior commissure rectimarginate. Number of ribs $7-8$ in $5 \mathrm{~mm}$ at $5 \mathrm{~mm}$ from ventral beak, $8-10$ at the anterolateral margin. Imbrication developed all over the surface. Lateral profile of the ventral valve plain, the highest point at apex. Ventral interarea up to $25 \mathrm{~mm}$ high, planar to concave, catacline.

Discussion. V. phrygia differs greatly from other Vellamo species in its high ventral valve, semicircular outline and typical imbricative sculpture. A specimen of $V$. cf. phrygia (Pl. V, fig. 3) shows an apsacline, high ventral valve, but lacks imbrication. However, the growth lines are uncommonly strong.

Occurrence. Keila Stage. Saue and Oandu outcrops. Padise core - $11.0 \mathrm{~m}$. 
1934 Vellamo symmetrica n. sp.; Öpik, p. 106, pl. 13, figs. 2, 3.

Holotype. Ventral valve IGT Br 484; Vormsi Stage, Paluküla, Estonia.

Remarks. V. symmetrica occurs in the Vormsi Stage together with $V$. leigeri and $V$. verneuilii. It differs from them in subquadrate outline and absence of imbrication.

\section{Vellamo aenigma Öpik, 1934 \\ Plate VI, figures $1-3,6$}

1934 Vellamo aenigma n. sp.; Öpik, p. 117, pl. 19, figs. 8a-c.

Holotype. Silicified ventral valve IGT Br 518; Porkuni, Estonia. A redeposited specimen from Quaternary till. Nabala, Vormsi or Pirgu stages.

Material. 4 complete shells; 5 ventral valves, 2 of them partly silicified; one silicified fragment of ventral valve; 5 dorsal valves.

Diagnosis. Shell up to $30 \mathrm{~mm}$ long and up to $40 \mathrm{~mm}$ wide, semiovate to semicircular. Maximum width of the shell at hinge line or slightly anterior to hinge line. Cardinal extremities acute, sides straight, anterior margin rounded, anterior commissure rectimarginate. Number of ribs $9-10$ in $5 \mathrm{~mm}$ at $5 \mathrm{~mm}$ from ventral beak, 6-9 at the anterolateral margin. Lateral profile of the ventral valve plain, with the highest point at apex. Ventral interarea up to $13 \mathrm{~mm}$ high, planar, apsacline. Foramen apical, sealed. Dorsal valve flat, without sulcus.

Discussion. $V$. aenigma occurs in the Pirgu Stage together with $V$. verneuilii and differs from it in flat ventral valve and fine ornamentation. From other species of Vellamo it differs in the high, apical position of small foramen, about 1-2 $\mathrm{mm}$ in diameter.

Occurrence. Vardi and Ümeru outcrops. Lower part of the Pirgu Stage. The material described by Öpik (1934) was collected from till at Porkuni and its original stratigraphical position is not clear.

\section{Vellamo magna Öpik, 1934 \\ Plate VI, figures 4, 5, 7-10}

1934 Vellamo magna n. sp.; Öpik, pp. 109-110, pl. 12, figs. 7, 8.

Holotype. Ventral valve IGT Br 496; Keila Stage, Rakvere, northern Estonia.

Material. 6 complete shells, 29 ventral valves, 12 dorsal valves.

Diagnosis. Shell up to $30 \mathrm{~mm}$ long and up to $37 \mathrm{~mm}$ wide; semiovate, semicircular, or subquadrate. Maximum width of the shell at hinge line to at midlength, cardinal 
extremities acute to obtuse, sides straight, anterior margin emarginate to rounded, anterior commissure rectimarginate to sulcate. Number of ribs $9-10$ in $5 \mathrm{~mm}$ at $5 \mathrm{~mm}$ from ventral beak, 8-9 at the anterolateral margin. Lateral profile of the ventral valve plain to convex, the highest point at apex to slightly anterior to apex. Ventral interarea up to $17 \mathrm{~mm}$ high. Spondylium simplex supported by ridge extending to anterior margin. Dorsal valve flat, without sulcus or with weak sulcus.

Discussion. V. magna occurs in the Keila Stage together with V.emarginata, $V$. ambisulcata, $V$. phrygia, and $V$. oandoensis. An adult specimen of $V$. magna is easily distinguishable from those by larger size, subquadrate shell shape, and straight sides. The dorsal valve of a preadult specimen resembles that of $V$. wesenbergiensis. The main difference is the finer ornamentation of V. magna.

Occurrence. Keila Stage. Jälgimäe, Kehra, Oandu, Rakvere, Saku, Saue, Sõmeru, and Tuula outcrops. Saku core - 11.1-11.4 m.

\section{Vellamo wesenbergiensis (Pahlen, 1877) \\ Plate VI, figures 11-18}

1877 Orthisina verneuilii wesenbergiensis Pahlen, p. 35, pl. 4, figs. 7-10.

1934 Vellamo wesenbergensis (Pahlen); Öpik, p. 108, pl. 10, figs. 2-5, 8-10; pl. 30, fig. 2.

1934 Vellamo wesenbergensis auriculata Öpik; Öpik, p. 109, pl. 10, figs. $6 \mathrm{a}, \mathrm{b}, 7$.

1953 Vellamo wesenbergensis (Pahlen); Alikhova, p. 82, pl. 11, figs. 1-8. non 1973 Vellamo wesenbergensis (Pahlen); Nasedkina, p. 124, pl. 22, figs. 4, 8.

Neotype. Complete shell IGT Br 494; Rakvere Stage, Rägavere, Estonia.

Material. 14 complete shells, 9 ventral valves, 13 dorsal valves.

Diagnosis. Shell up to $30 \mathrm{~mm}$ long and up to $37 \mathrm{~mm}$ wide, semiovate. Maximum width of the shell at hinge line to at midlength, cardinal extremities acute to obtuse, sides concave to straight, anterior margin emarginate to rounded, anterior commissure rectimarginate to sulcate. Number of ribs $5-7$ in $5 \mathrm{~mm}$ at $5 \mathrm{~mm}$ from ventral beak, 6-8 at the anterolateral margin. Lateral profile of the ventral valve plain to convex, the highest point at apex to slightly anterior to apex. Ventral interarea up to $13 \mathrm{~mm}$ high, planar to concave, apsacline. Dorsal valve flat to slightly concave, without sulcus or with weak sulcus.

Discussion. $V$. wesenbergiensis is closely similar to $V$. verneuilii, differing in open foramen of adult specimens and slightly coarser ornamentation. The outline is typically semiovate, never shows bulging anterior margin as in $V$. verneuilii. $V$. wesenbergiensis is the only species in the Rakvere Stage.

Nasedkina (1973) described 57 specimens from the Rassocha Stage (Ashgill), the Rassocha River, western slope of the North Urals as Vellamo wesenbergiensis. The described species differs from the Estonian species in having a convex dorsal valve and ornamentation about twice as fine (10-12 ribs 
per $5 \mathrm{~mm}$ ) as in the Estonian species. Obviously the described specimens belong to a different species.

Occurrence. Rakvere Stage. Rägavere and Rakvere outcrops. Ingria (Alikhova, 1953).

\section{DEVELOPMENT OF THE GENUS VELLAMO IN ESTONIA}

Vellamo is a widely spread clitambonitidine genus in the middle-upper Ordovician. Of 34 species assigned, 16 have been described from Estonia and Ingria (St Petersburg region). Their distribution of the species is summarized in Table 2. Three distinct stages can be noted in the development of the genus: early Viru, mid-Viru, and late Viru/Harju.

Table 2

Stratigraphical distribution of Estonian Vellamo species

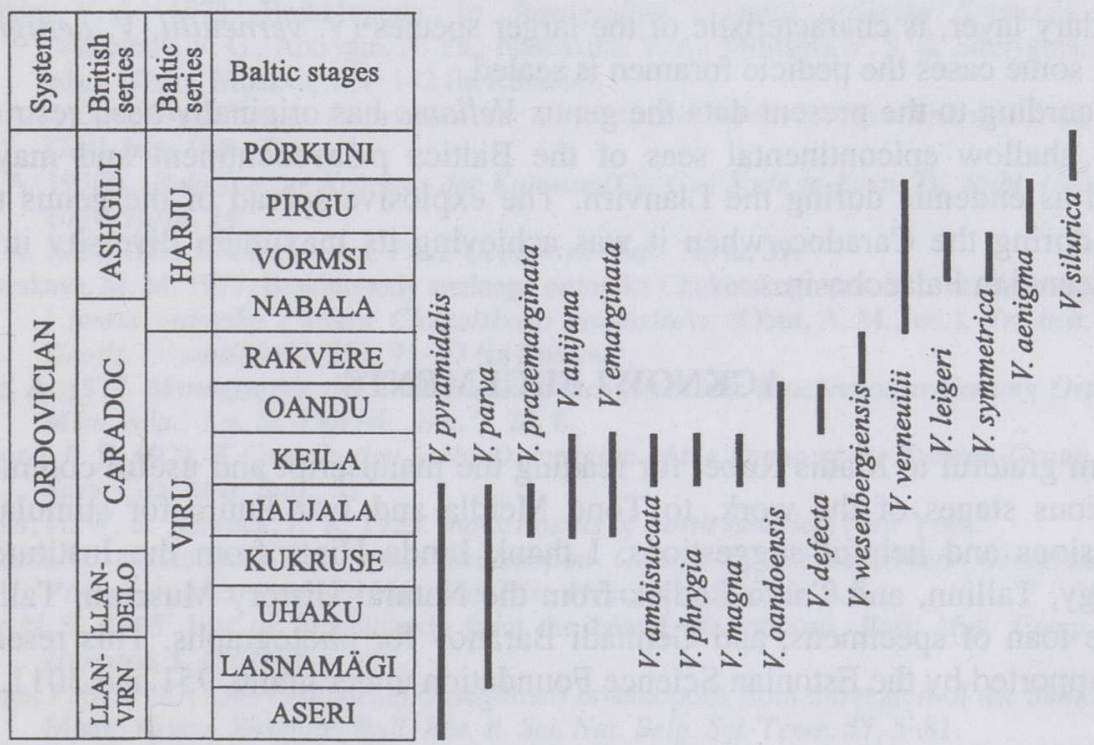

The earliest known Vellamo species is $V$. pyramidalis, which appeared in the Aseri time. V. parva appeared in the Lasnamägi Stage. Both species are small to medium-sized and characterized by thin shells. They are the only representatives of the genus during the early Viru epoch, the Kukruse time inclusive.

The mid-Viru development stage began with the appearance of three new species - V. anijana, $V$. praeemarginata, and $V$. emarginata - in the Haljala time. The Keila time marked the highest diversity for the genus Vellamo; four new species were added to the record: V. ambisulcata, V. phrygia, V. magna, and $V$. oandoensis. All nine species which existed during the Keila time show indisputably different sets of characters and should be regarded as valid taxa. The 
Vellamo species of medium size prevailed during the Keila time, but some species with a thick shell and anteriorly arranged notothyrial platform are recorded as well (V. magna, V. ambisulcata). Of the nine Keila species, only V. oandoensis continued its existence during the Oandu time. A remarkable diversity fall cooccurs with the Keila/Oandu boundary event which is well documented in the Estonian succession (Hints et al., 1989).

The post-Keila epoch shows mostly successive taxa. Apart from V. oandoensis, the single specimen of $V$. defecta is documented from the Oandu Stage. In the Rakvere Stage, only $V$. wesenbergiensis has been recorded. In the Nabala Stage it was replaced by $V$. verneuilii, the type species of the genus. This species is the most common Vellamo species in the Harju Series, ranging into the Porkuni Stage. The Vormsi time marks the appearance of $V$. leigeri and $V$. symmetrica, rare shortranged taxa with very distinct sets of morphological characters. The rare species, $V$. aenigma of the Pirgu time and $V$. silurica of the Porkuni time complement the record of Vellamo in the Ordovician of Estonia. Within the species of the Harju epoch, medium-sized species are common while the maximum size of the species gradually increases at the end of the Ordovician. A heavy shell, with a thick secondary layer, is characteristic of the larger species (V. verneuilii, V. aenigma), and in some cases the pedicle foramen is sealed.

According to the present data the genus Vellamo has originally been restricted to the shallow epicontinental seas of the Baltica palaeocontinent and may be treated as endemic during the Llanvirn. The explosive spread of the genus took place during the Caradoc, when it was achieving its maximum diversity in the Baltoscandian Palaeobasin.

\section{ACKNOWLEDGEMENTS}

I am grateful to Madis Rubel for reading the manuscript and useful comments at various stages of the work, to Tõnu Meidla and Ivar Puura for stimulating discussions and helpful suggestions. I thank Linda Hints from the Institute of Geology, Tallinn, and Toivo Lodjak from the Natural History Museum, Tallinn, for the loan of specimens, and Gennadi Baranov for photographs. This research was supported by the Estonian Science Foundation under grants 951 and 3011.

\section{REFERENCES}

Alikhova, T. N. 1953. Rukovodyashchaya fauna brakhiopod ordovikskikh otlozhenij severozapadnoj chasti Russkoj platformy. Gosudarstvennoe Izdatel'stvo Geologicheskoj Literatury, Moskva (in Russian).

Bolton, T. E. 1961. Ordovician and Silurian formations of Anticosti Island, Quebec. Bull. Geol. Surv. Can., 61, 26, 1-18.

Bondarev, V. G. 1968. Stratigrafiya i kharakternye brakhiopody ordovikskikh otlozhenij yuga Novoj Zemli, o. Vaigach i severnogo Paj-Khoya. Trudy NIIGA, 157, 3-144 (in Russian).

Cocks, L. R. M. 1978. A Review of British Lower Palaeozoic Brachiopods, Including a Synoptic Revision of Davidson's Monograph. Palaeontogr. Soc. Monogr. Lond., 131, 549.

Davidson, T. 1883. Monograph of the British Fossil Brachiopoda. Silurian Supplement. Vol. 5, Pt. 2., Palaeontogr. Soc., London. 
Eichwald, E. 1841. Die Uhrwelt Russlands durch Abbildungen erlaeutert. St. Petersburg.

Fu, Li-Pu. 1982. Palaeontological Atlas of Northwest China. Precambrian and Early Paleozoic, Shaanxi-Gansu-Ningxia, Vol. 1. Geological Publishing House, Beijing, China.

Harper, D. A. T. 1989. Brachiopods from the Upper Ardmillian Succession (Ordovician) of the Girvan District, Scotland, Part 2. Palaeontogr. Soc. Monogr. Lond., 142, 579, 79-128.

Hiller, N. 1980. Ashgill Brachiopoda from Gill Ceiriog District, North Wales. British Mus. (Nat. Hist.), Geol. Ser., 34, 3, 109-216.

Hints, L., Meidla, T., Nõlvak, J. \& Sarv, L. 1989. Some specific features of the Late Ordovician evolution in the Baltic basin. Proc. Acad. Sci. ESSR. Geol., 38, 2, 83-87.

Kaljo, D. 1951. Nõukoguliku evolutsioonilise paleontoloogia meetodite rakendamine perekond Vellamo uurimisel. Tartu (manuscript, Institute of Geology, University of Tartu).

Laurie, J. R. 1991. Articulate brachiopods from the Ordovician and Lower Silurian of Tasmania. In Australian Ordovician Brachiopod Studies (Jell, P. A., ed.). Mem. Ass. Australas. Palaeontols., 11, 1-106.

Mitchell, W. I. 1977. The Ordovician Brachiopoda from Pomeroy, Co. Tyrone. Palaeontogr. Soc. Monogr. Lond., 130, 545.

Murchison, R. J., de Verneuil, E. \& de Keyserling, A. 1845. Geologie de la Russie d'Europe et des montagnes de l'Oural. Paleontologie, 2. Londres-Paris.

Nasedkina, V. A. 1970. Predstaviteli roda Vellamo v ordovikskikh otlozheniyakh zapadnogo sklona Urala. In Materialy po paleontologii Urala (Breivel, I. A. \& Papulov, G. N., eds.). Akad. Nauk. SSSR, Uralskij Filial, Sverdlovsk, 43-51 (in Russian).

Nasedkina, V. A. 1973. Brakhiopody. In Stratigrafiya $i$ fauna ordovika Srednego Urala (Varganov, V. G., Antsygin, N. Ya., Nasedkina, V. A., Militsina, V. S. \& Shurygina, M. V., eds.). Nedra, Moskva, 111-142 (in Russian).

Öpik, A. 1930a. Brachiopoda Protremata der estländischen ordovizischen Kukruse-Stufe. Publ. Geol. Inst. Univ. Tartu, 1.

Öpik, A. 1930b. Beiträge zur Kenntnis der Kukruse-( $\left.C_{2^{-}} C_{3^{-}}\right)$Stufe in Eesti, IV. Publ. Geol. Inst. Univ. Tartu, 24.

Öpik, A. 1934. Über Klitamboniten. Publ. Geol. Inst. Univ. Tartu, 39.

Oradovskaya, M. M. 1977. Brakhiopody srednego ordovika Chukotskogo poluostrova. In Stratigrafiya $i$ fauna ordovika $i$ silura Chukotskogo poluostrova (Obut, A. M., ed.). Tr. Inst. Geol. Geofiz. (Novosibirsk), 351, 91-93 (in Russian).

Pahlen, A. 1877. Monographie der baltisch-silurischen Arten der Brachiopoden-Gattung Orthisina. Mém. Acad. Sci. St.-Pétersb., Ser. 7, 24, 8.

Raymond, P. E. 1921. A Contribution to the Description of the Fauna of the Trenton Group. Geol. Surv. Can. Mus. Bull., 31.

Schimer, H. W. \& Schrock, R. R. 1955. Index Fossils of North America. New York.

Schuchert, C. \& Cooper, G. A. 1932. Brachiopod Genera of the Suborders Orthoidea and Pentameroidea. Peabody Mus. Nat. Hist. Mem., New Heaven, 4, 1.

Shaler, N. S. 1865. List of Brachiopoda from the Island of Anticosti. Bull. Mus. Comp. Zool. Harvard, 1, 4, 61-70.

Sheehan, P. M. 1987. Late Ordovician (Ashgillian) brachiopods from the region of the Sambre and Meuse Rivers, Belgium. Bull. Inst. R. Sci. Nat. Belg. Sci. Terre, 57, 5-81.

Termier, H. \& Termier, G. 1950. Contribution a l' Étude des Faunes Paléozoïques de L'Algérie. Bull. Serv. Carte Géol. Algér., Trav. Lab. Géol. Fac. Sci. Alger., 1, 11, 11-52.

Tsegelnyuk, P. D. 1976. Brakhiopody $i$ stratigrafiya nizhnego paleozoya Volyno-Podolii. Nauka, Kiev (in Russian).

Twenhofel, W. H. 1927. Geology of Anticosti Island. Mem. Geol. Surv. Can., 154. F. A. Ackland, Ottawa.

Williams, A. 1963. The Caradocian Brachiopod Faunas of the Bala District, Merionetshire. Bull. British Mus. (Nat. Hist.) Geol., 8, 7.

Williams, A. \& Wright, A. D. 1965. Orthida. In Treatise on Invertebrate Paleontology Brachiopoda, H. (Moore, R. C., ed.). Univ. Kansas Press \& Geol. Soc. Am., Lawrence, H299-H359.

Wilson, A. 1946. Brachiopoda of the Ottawa Formation of the Ottawa-St. Lawrence Lowland. Bull. Geol. Surv. Can., 8, 114-129.

Wright, A. D. 1964. The Fauna of the Portrane Limestone, II. Bull. British Mus. (Nat. Hist.) Geol., 9, 6, 241-256. 
Wright, A. D. 1981. The external surface of Dictyonella and other pitted brachiopods. Palaeontology, 24, 3, 443-481.

Wright, A. D. \& Rubel, M. 1996. A review of the morphological features affecting the classification of clitambonitidine brachiopods. Palaeontology, 39, 1, 53-75.

\section{ORDOVIITSIUMI BRAHHIOPOODIPEREKOND VELLAMO EESTIS}

\section{Oive TINN}

Ordoviitsiumi brahhiopoodiperekond Vellamo Öpik, 1930 on Eestis esindatud 16 liigiga. Teadaolevalt vanim on $V$. pyramidalis Pahlen, mis stratigraafiliselt levib Aserist kuni Haljala lademeni. Paralleelselt eelmisega on alates Lasnamäe lademest teada V. parva Öpik'u esinemine. Mõlemad kuuluvad väikeste kuni keskmiste, suhteliselt õhukese kojaga liikide hulka ning eristuvad rõõnestuse tiheduse poolest.

Suurima liigilise mitmekesisusega paistavad silma Haljala ja Keila lade, kus perekond Vellamo koosluse moodustavad üheksa, peamiselt keskmise kojasuurusega liiki. Sellel tasandil ilmuvad esimesed paksu koja ning nototüriaalse lava eesmise asetusega liigid $V$. ambisulcata Öpik ning V. emarginata Pahlen.

Pärast Keila aega on valdavad tihedalt üksteisele järgnevad, väikese stratigraafilise levikuulatusega liigid. Neile on iseloomulik keskmine kuni suur koda ning paks teisene kiht, mis mõningatel juhtudel (V. verneuilii Eichwald) täidab pediikli foraameni.

\section{ОРДОВИКСКИЕ БРАХИОПОДЫ РОДА VELLAMO В ЭСТОНИИ}

\section{Ойве ТИНН}

Ордовикские отложения Эстонии представлены 16 видами брахиопод рода Vellamo Öpik, 1930. По имеющимся данным, старейший из них $V$. pyramidalis Pahlen - стратиграфически распространен от азериского до хальялаского горизонта. Параллельно последним, начиная с ласнамяэского горизонта, появляется $V$. parva Öpik. Оба вида имеют раковину размером от малого до среднего и отличаются друг от друга характером ребристости.

Наибольшим видовым разнообразием выделяются хальялаский и кейлаский горизонты, где род Vellamo представлен девятью видами, раковина которых среднего размера. На этом же уровне впервые встречаются виды с толстой раковиной и передним расположением на ней нототириальной платформы (V. ambisulcata Öpik и $V$. emarginata Pahlen).

Послекейлаские отложения содержат плотно следующие друг за другом, но с коротким стратиграфическим распространением виды. Для них характерны раковина размером от среднего до большого и толстый вторичный слой, который у некоторых экземпляров покрывает примакушечную часть раковины и форамен (V. verneuilii Eichwald). 